\title{
A GENETIC AND BEHAVIORAL ANALYSIS OF MATE CHOICE AND SONG NEIGHBORHOODS IN INDIGO BUNTINGS
}

\author{
ROBERT B. PAYNE \\ Museum of Zoology and Department of Biology, The University of Michigan, Ann Arbor, MI 48109 \\ AND \\ DAVID F. WESTNEAT' \\ Department of Biology, University of North Carolina, Chapel Hill, NC 27514
}

\begin{abstract}
Neighboring males of indigo buntings (Passerina cyanea) share songs in southern Michigan. We sampled polymorphic enzymes to compare the genetic variation between mates and the variation among contiguous song neighborhoods. Mate choice was independent of the genetic and morphometric similarity of female and male, and these measures were independent of each other. The incidence of extrapair copulations and fertilizations was independent of the song of cuckolding males. Breeding success of the mated pairs was independent of their genetic or morphological similarity. Males characterized by different song dialects did not differ in mean lifetime reproductive success. We found no significant genetic differences among the neighborhoods. Most birds that bred in one song neighborhood were born in another, and neighborhoods were not isolated demes. Bunting songs may provide no information to a female about genetic quality of males. The results are consistent with a neutral model of no mate choice for genes.
\end{abstract}

Received May 21, 1987. Accepted April 4, 1988

Mate choice for genes implies that females choose among males that differ genetically (Parker, 1983). Some conspicuous traits such as male size and behavior may be both heritable and behaviorally assessable by a female, but choice for genes may be cryptic (the phenotypic trait used by a female is not evident to a biologist). The hypothesis that traits evolve through sexual selection by mate choice leads to two sets of predictions: females mate nonrandomly with males that have certain heritable traits, and individuals with these varying traits differ in their reproductive success.

Songbirds attract mates by singing, and male song may be modified by mate choice through sexual selection (Payne, 1983a; Searcy and Andersson, 1986). In this context, the hypothesis of mate choice for genes predicts that male song covaries with genetic differences, and females use song to assess the genetic quality of males. Female assessment may involve comparison of males within or among populations. Where songs vary locally, females may choose males with a song that matches the song of their father or their natal neighborhood, and

\footnotetext{
${ }^{1}$ Present address: Section of Genetics and Development, Emerson Hall, Cornell University, Ithaca, NY 14853.
}

we might find genetic differences among neighborhoods with different songs. If song dialects correspond with demes that are adapted to local conditions, then females choosing males with songs like the ones they heard in their natal area might be selecting mates with compatible genes (Marler and Tamura, 1962; Payne, 1981a). A female might also compare a male's song with her father's, thereby using song to recognize kin and to avoid incestuous matings or to optimally inbreed with relatives having a similar genetic background (McGregor and Krebs, 1982a, 1982b; Shields, 1982; Bateson, 1983; Sherman and Holmes, 1985). To interpret genetic differences observed in field samples, we should know the population structure by direct observation of movements of individuals from natal to breeding locations, the breeding success of individuals that mate with relatives and with nonkin, the heritability of song and morphology, and the extent to which song and morphology are behaviorally available as kinship cues in female choice. Techniques for estimating genetic differences among individuals have been available for more than 20 years, but field biologists have seldom combined behavioral, population, and genetic approaches in tests of evolutionary hypotheses (e.g., Lewontin, 1974; Boag and 
Grant, 1981; Sherman, 1981; Price, 1984; Slatkin, 1985; Endler, 1986).

Indigo buntings (Passerina cyanea) are common in southern Michigan, where we have observed these small songbirds since 1978 (Payne et al., 1981, 1987, 1988; Payne, 1982, 1983a, 1983b; Westneat, 1986, 1987a, 1987b; Westneat et al., 1986). Buntings are usually socially monogamous with males and females in pairs, but about $15 \%$ of the breeding males have more than one female nesting on a territory. Genetic differences among individuals were estimated electrophoretically to determine the incidence of nestlings that were not genetically consistent with the adults thought to be their parents (Westneat, 1987b). Songs and mate choice were compared among birds of known family histories to determine whether these covary with kinship (Payne et al., 1987). Here we ask the following questions about mate choice and its genetic consequences. 1) Do females mate with males at random with respect to genetic information accessible by behavior, morphology, and electrophoretic genotype? 2) Are birds with different song dialects genetically distinguishable? 3 ) Is breeding success related to the degree of genetic or phenotypic assortative mating? 4) Does breeding success of males differ among song dialects?

\section{Materials ANd Methods}

We banded and color-marked buntings in a $4 \mathrm{~km}^{2}$ study area near Niles, Cass County, southwestern Michigan, from 1978 through 1987. We found nests and banded the nestlings at an age of 4-7 days. When the young returned in a later breeding season to their natal area after a long-distance migration from their wintering areas in the neotropics, we recaptured, color-marked, measured, and released them. We observed behavior and breeding success of all birds through each breeding season, and survival of returning buntings through 1987 . We biopsied adults and nestlings from 1983 through 1985 by removing a strip of pectoral muscle (Westneat et al., 1986). We biopsied most individuals only once in their lifetime, but did a few more than once to verify the electrophoretic results.

Muscle samples were placed in Tris-
EDTA-HCl buffer at pH 7.4 (Selander et al., 1971) and frozen on dry ice. The biopsy was nondestructive and did not affect the breeding success and survival of adult buntings (Westneat et al., 1986). Soluble muscle enzymes of 148 males and 117 females were later analyzed with standard techniques of horizontal starch-gel electrophoresis (Shaw and Prasad, 1970; Selander et al., 1971; Harris and Hopkinson, 1976). Enzymes tested were those known to be polymorphic in other avian species (Barrowclough and Corbin, 1978; Avise et al., 1980a, 1980b; Zink, 1982). The enzymes (and loci) were $\alpha$-glycerophosphate dehydrogenase ( $\alpha G p d$ ), 6-phosphogluconate dehydrogenase $(6 \mathrm{Pgd})$, glutamate oxaloacetate transaminase (Got), phosphoglucomutase (Pgm), phosphoglucose isomerase $(P g i)$, isocitric dehydrogenase $(I d h)$, mannose phosphate isomerase ( $M p i)$, peptidase B (Pept B), and peptidase $\mathrm{C}($ Pept $C)$. The gel and buffer systems are described in Westneat $(1987 b)$. Eight loci were found to be polymorphic in 1983 and a ninth $(M p i)$ was added to the sample repertoire in the next two years. The banding patterns were consistent with those expected from the known enzyme structure, and genotype frequencies were consistent with expectations of binomial distributions in all but one presumptive locus in one year. The loci segregated independently, and the sexes did not differ in allele distribution (Westneat, $1987 b$ ).

We scored the number of loci with identical genotypes in the male and female of each pair based on electromorph information. The proportion of loci identical between mates was used as an index of their genetic similarity. For example, if a female and a male were found to possess the same genotype at all but one locus, at which they shared either one allele or none, they were scored as having seven of eight loci in common, resulting in a genetic similarity of 0.875 . We estimated a second genetic index by scoring the kinds of possible heterozygous combinations that each pair could produce at fertilization; this ranged from 0 to 4 at each locus. The scores were summed, and then scaled to a range of 0 to 1 by dividing the sum by 32 (four maximum combinations possible $\times$ eight loci). As the two genetic indices were closely correlated 
(Pearson product-moment $r=-0.951, P$ $\ll 0.01$ ) and gave similar result associations with other variables of mate similarity, morphology, and breeding success, we present only the values for genetic similarity.

We also marked and observed buntings for ten years in a second population located on $12 \mathrm{~km}^{2}$ of open and shrubby habitat in southeastern Michigan on the E. S. George Reserve and neighboring lands in Livingston County (Payne, 1982, 1983a, 1983 $b$; Payne et al., 1987, 1988). The study areas were $250 \mathrm{~km}$ apart; no birds were seen on both. The two areas allowed replication of all tests except those involving electromorphic variation.

We based our genetic analysis of population structure on Wright's $F_{\mathrm{ST}}$ statistic, which estimates the proportion of genetic variation in a population that is due to differences among its subpopulations. We estimated $F_{\text {ST }}$ values from the frequency of observed putative genotypes with a mean likelihood method (Long, 1986; Smouse and Long, 1988). The $F_{\text {ST }}$ statistic ranges from 0 to 1.0 ; the latter is the limit of differentiation under fixation of alternative alleles in different subpopulations (Wright, 1978; Hartl, 1980). As the variances of $F$-statistics estimates are high and unstable when the most common allele is above 0.9 (as in our data) and $F$-statistic estimators are not normally distributed (Long, 1986), we did not estimate confidence intervals; instead, we tested the null hypothesis $\left(\mathrm{H}_{0}: F_{\mathrm{ST}}=0\right)$ with an approximate method (Long, 1986).

Males were tape recorded repeatedly through all seasons and their songs were analyzed with a Kay Elemetrics Vibralyzer $7030 A$. Songs were compared visually and notes of "song figures" of audiospectrograms were coded from a directory (Thompson, 1970). Buntings have a single song type, which most yearling males copy from a territorial neighbor during their first breeding season and retain through later years. Most males share their song with one or more territorial neighbors. The audiospectrograms were compared visually (Fig. 1) and the coded sequences of song figures were compared with a computer program MATCH, which compares sequences to identify regions of similarity (Payne et al., 1981). We considered songs to match if two or more birds had the same sequence of at least three different song figures. A match of three figures resulted, almost always, in a total match of all figures. Nearly all matching males were on adjacent territories. The occasional neighbors with songs having an odd note or missing a note within this minimal sequence were considered to match; this criterion of three notes out of four allowed us to match songs that changed over years due to minor "errors" in copying and to recognize the cultural evolution of the song traditions (Payne et al., 1981, 1988; Payne, unpubl.). Each distinctive song pattern is called a "song type," song types shared by two or more birds are called "dialects," and a song "neighborhood" consists of males with the same song type and their mates. Song neighborhoods within a population averaged only 3-5 males in a year and about the same number of females, but some had as many as 20 males. The largest song neighborhoods $(39,40$, and 52) were compared for genetic variation among subpopulations characterized by their song. Neighborhoods 39 and 40 were recorded and observed each year from 1978 through 1987; neighborhood 52 was observed from 1981 , when a bird with this song dispersed into the study area, which was then extended to include this marginal neighborhood and beyond, through 1987.

We determined the breeding success of all buntings in both areas by searching for nests from May through August and visiting the nests often enough to determine the number of young that survived to fledge. It is unlikely that any successful nestings in the main song neighborhoods escaped our notice. We established lifetime reproductive success by compiling across years the seasonal breeding success of each bird banded as a yearling until the year it did not return to the study area. We checked for local dispersal throughout each season as we observed all birds in the study area, which was extended each year and eventually included about ten times the size of the total area of the song neighborhoods described here. Local dispersal was detected among only four of the 89 males $(<5 \%)$ involved in the song neighborhoods for which we determined lifetime success. We also searched for dispersing birds in habitats within one 

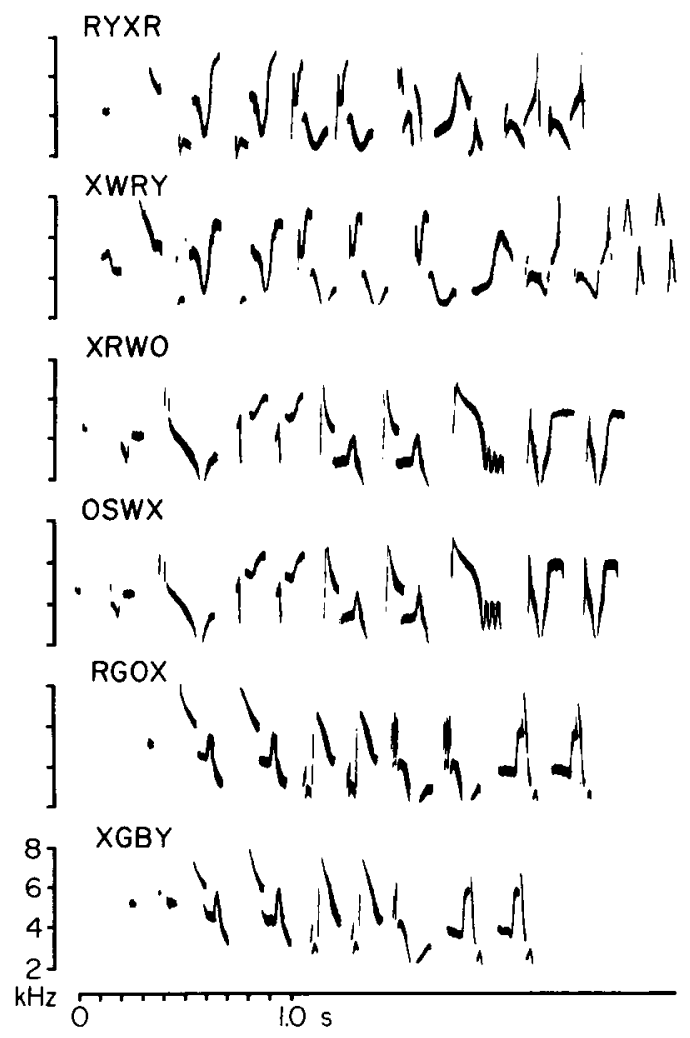

FIG. 1. Audiospectrograms of songs of six indigo buntings in three contiguous song neighborhoods at Niles, Michigan. Males RYXR and XWRY have song type 39, XRWO and OSWX have song type 40, and RGOX and XGBY have song type 52 .

$\mathrm{km}$ of the boundaries of the study area and found none from these song neighborhoods.

We examined the yearlings and adults when we caught them for banding and biopsy. We measured wing length (arc) from the bend of the wing to the tip of the longest feather with the wing flattened against a rule, bill length from the feathered base to the tip of the upper mandible, and tarsus from the proximal end of the tibiotarsus to the distal margin of the last undivided scute at the base of the toes. We determined the ages of the males by their greater primary coverts, blue in adults (more than one year of age) and brown in first-year birds (Payne, 1982; Payne et al., 1988). A comparison of firstyear males with adults and of recaptured adults that had been measured as first-year birds in an earlier year showed an increase in mean wing length of $1.0 \mathrm{~mm}$. Certain banders had different means for some mea- surements. We standardized the measurements with respect to age (adding $1.0 \mathrm{~mm}$ to yearling male wing length) and bander.

\section{RESULTS}

Genetic and Morphometric Comparisons of Mates. - Was mating of female buntings independent of the male's genotype? Comparing the first known banded mate of each female, where we had genotypic data for all eight loci in both male and female $(N=65$ pairs), the genetic similarity between members of a pair ranged from 0.375 to 1.0 and averaged $0.832 \pm 0.144 \mathrm{SD}$. To determine whether male and female genotypes were similar to those expected if females chose males independently of their similarity, we assigned mates at random (regardless of any previous matings; we allowed replacements in the pool of males, as we saw replacements in the natural mated pairs) to each of the 65 females from the complete sample of 87 males with information for all eight loci. Genetic similarity of the randomly assigned pairs averaged $0.804 \pm 0.140 \mathrm{SD}$. The distribution of similarities in the real pairs and the random pairs was nearly identical (Table 1; Mann-Whitney $U$ test, $z=0.30$, ns).

Phenotypic assortative mating was tested by comparing measurements of wing, tarsus, and bill length in the 65 mated pairs of buntings with genotype information at the eight loci. Females mated without regard to the relative size of the male (Table 2).

Genetic and Morphometric Comparisons of Song Populations. - Are local song neighborhoods genetically differentiated? Genotype frequencies were compared among the three song neighborhoods with 15 or more sampled adults (Table 3 ). The neighborhoods were contiguous (some males in neighborhood 40 were on territories bordering males in 39, and others in 40 bordered males in 52) and linearly distributed along a railway with the extreme birds 1,500 $m$ apart. The sample included about half of the individual adults in the three neighborhoods over the three years. The number of males in each neighborhood ranged from eight to 14 in the three years, the number of females was similar but not known precisely because not all were banded and both males and females may have more than one mate in a season (Payne, 1982; Payne et al., 
TABle 1. Frequency distribution of genetic similarities of actual and random mated pairs of indigo buntings.

\begin{tabular}{lccccccccc}
\hline \hline & $\begin{array}{l}\text { Num- } \\
\text { ber of } \\
\text { pairs }\end{array}$ & \multicolumn{1}{c}{ Number of loci with identical genotypes } \\
\cline { 3 - 10 } & 65 & 2 & 3 & 4 & 5 & 6 & 7 & 8 \\
\hline Actual & 65 & 0 & 1 & 1 & 13 & 8 & 27 & 16 \\
Random & 65 & 0 & 0 & 0 & 2 & 12 & 20 & 18 & 13 \\
\hline
\end{tabular}

1988). Most adults returned from year to year. For each locus, the same genotype was predominant in all three neighborhoods. Interpreting the negative estimates (which result from the mean likelihood method) of $F_{\text {ST }}$ as zero and weighting each locus by sample size and the number of alleles (Long, 1986), the mean $F_{\mathrm{ST}}$ for all nine loci was 0.0038 (Table 4 ); thus less than $1 \%$ of the total observed genetic variation was observed among song neighborhoods. The observed variation at each of the nine loci was not significantly different from what would be expected, according to a null hypothesis of no genetic differences among neighborhoods. We reason that the loci examined are representative markers of the variability among subpopulations. The ability to statistically discriminate differences in heterozygosities increases with sample size and the number of loci surveyed (Chakraborty, 1981). This sensitivity is not equally true for $F_{\mathrm{ST}}$ values which are defined as the proportion of variation in a population that is due to variation among subgroups. The samples were small (although they included half the number of breeding adults), but the inference of no important genetic differ- ences among the song populations is consistent with the observation that no case of marginal ambiguous statistical significance was seen.

Measurements of adult buntings were compared among neighborhoods to determine whether morphological traits varied with song. Heritability of size was estimated by comparing measurements of parents and offspring in a regression model; the relationship was significant (Payne, unpubl.). We tested for morphometric differences among the neighborhoods in each sex comparing mean values of wing arc, tarsus length, and bill length (ANOVA), with ten or more birds in each neighborhood (Table 5). At Niles, mean size of males did not differ significantly among neighborhoods, though mean wing length of females did. Female wing length overlapped considerably between all neighborhoods, and, as the means differed significantly in only six of $36 \mathrm{com}$ parisons (Scheffe pairwise $F$ tests, $P<0.05$ ), the differences in means may be due to sampling errors. At the George Reserve, we found no significant differences among neighborhoods in mean wing length among males or females. We conclude that the morphometric differences among bunting song neighborhoods are small and not significant.

Direct observation on individual dispersal from birth to site of first breeding is consistent with the indirect genetic and morphological estimates of a lack of local differentiation among song neighborhoods. From 1979 to 1987 , we recaptured 124 buntings during the breeding season, on the

TABLE 2. Relationships among genetic similarity, phenotypic similarity, and breeding success in 65 mated pairs of indigo buntings. None of the $F$ values was significant $(P>0.05)$.

\begin{tabular}{llrrc}
\hline \multicolumn{1}{c}{ Dependent value } & \multicolumn{1}{c}{ Independent variable } & \multicolumn{1}{c}{$b$} & $r^{2}$ & $F$ \\
\hline Male wing & female wing & -0.01 & 0.00 & 0.00 \\
Male tarsus & female tarsus & -0.06 & 0.00 & 0.23 \\
Male bill & female bill & -0.13 & 0.01 & 0.73 \\
Number of young fledged & genetic similarity & 0.34 & 0.04 & 2.78 \\
Number of young fledged & difference in wing length $(\mathrm{m}-\mathrm{f})$ & 0.04 & 0.00 & 0.28 \\
Number of young fledged & difference in tarsus length (m-f) & -0.49 & 0.05 & 3.54 \\
Number of young fledged & difference in bill length $(\mathrm{m}-\mathrm{f})$ & 0.09 & 0.00 & 0.14 \\
Number of young fledged & $\bar{x}-x_{i}$ male wing & -0.17 & 0.05 & 2.66 \\
Number of young fledged & $\bar{x}-x_{i}$ male tarsus & -0.24 & 0.06 & 3.80 \\
Number of young fledged & $\bar{x}-x_{i}$ male bill & -0.27 & 0.00 & 0.40 \\
Difference in wing length $(m-f)$ & genetic similarity & 0.13 & 0.03 & 2.18 \\
Difference in tarsus length $(\mathrm{m}-\mathrm{f})$ & genetic similarity & 0.17 & 0.00 & 0.25 \\
Difference in bill length $(\mathrm{m}-\mathrm{f})$ & genetic similarity & $-\mathbf{0 . 1 7}$ & 0.01 & 0.33 \\
\hline
\end{tabular}


TABLE 3. Number of individuals of each genotype in three song populations of indigo buntings.

\begin{tabular}{|c|c|c|c|c|c|c|c|c|c|c|c|c|c|c|c|c|c|c|}
\hline \multirow[b]{2}{*}{ Locus } & \multicolumn{6}{|c|}{ Neighborhood 39} & \multicolumn{6}{|c|}{ Neighborhood 40} & \multicolumn{6}{|c|}{ Neighborhood 52} \\
\hline & 11 & 12 & 13 & 22 & 23 & 33 & 11 & 12 & 13 & 22 & 23 & 33 & 11 & 12 & 13 & 22 & 23 & 33 \\
\hline$\alpha G p d$ & 20 & 1 & 0 & 0 & 0 & 0 & 16 & 0 & 0 & 0 & 0 & 0 & 24 & 1 & 0 & 0 & 0 & 0 \\
\hline $6 P g d$ & 0 & 0 & 0 & 20 & 1 & 0 & 0 & 0 & 0 & 15 & 0 & 0 & 0 & 1 & 0 & 23 & 0 & 0 \\
\hline Got & 1 & 4 & 0 & 16 & 0 & 0 & 0 & 1 & 0 & 13 & 1 & 0 & 0 & 1 & 0 & 20 & 0 & 0 \\
\hline$P g m$ & 0 & 0 & 0 & 21 & 0 & 0 & 0 & 0 & 0 & 15 & 0 & 0 & 0 & 1 & 0 & 25 & 0 & 0 \\
\hline$P g i$ & 19 & 2 & 0 & 0 & $\mathbf{0}$ & 0 & 14 & 1 & 0 & 0 & 0 & 0 & 23 & 2 & 0 & 0 & 0 & 0 \\
\hline$I d h$ & 20 & 0 & 0 & 0 & 0 & 0 & 12 & 1 & 0 & 0 & 0 & 0 & 20 & 2 & 0 & 0 & 0 & 0 \\
\hline$M p i$ & 0 & 0 & 0 & 12 & 0 & 0 & 0 & 0 & 0 & 10 & 2 & 0 & 0 & 1 & 0 & 19 & 1 & 0 \\
\hline Pept B & 0 & 2 & 0 & 17 & 1 & 1 & 0 & 2 & 0 & 13 & 0 & 0 & 1 & 1 & 0 & 23 & 0 & 0 \\
\hline Pept $C$ & 20 & 1 & 0 & 0 & 0 & 0 & 11 & 1 & 0 & 0 & 0 & 0 & 23 & 2 & 0 & 0 & 0 & 0 \\
\hline
\end{tabular}

study area where we had banded them as nestlings. In song neighborhoods 39,40 , and 52 , we recaptured 30 buntings that we had banded in an earlier year as nestlings. Only five were reared in the song neighborhood to which they returned; the other 25 were born in a different neighborhood. Likewise, breeding pairs in these three neighborhoods had a total of 22 banded nestlings that returned in a later year, but only five of these nested in their natal neighborhood.

Breeding Success and the Similarity of Mates. - The importance to females of choosing a mate with a particular genetic makeup can be tested by comparing their success in leaving offspring. The number of young that survived to fledge during the first year the pair was mated was compared in relation to the genetic and morphometric similarities of the pair.

Genetic similarity of pairs was not significantly different for the $\mathbf{4 8}$ successful and the 17 unsuccessful pairs (Mann-Whitney $U$ test, $z=1.17$, ns). The number of young fledged by the 65 mated pairs with known genotypes in their first season as mates ranged from zero to seven and averaged 2.38 $\pm 1.88 \mathrm{SD}$. Breeding success of the mated pairs was independent of their genetic similarity (Table 2).

Morphometric traits might be useful to a female in mate choice if match or complementarity of a mate's genotype with her own could affect the development of her young (Fleischer et al., 1983). Behavioral information about genetic matching might be available if she compared size of a male with other males or with her own phenotype. If matching of genes that affect morphometric traits or that are linked to these is important, then pairs where the male and female are similar in size should have higher (or lower) success than other pairs in leaving offspring. The breeding success of mated

TABLE 4. Estimated $F^{*}$ ST statistics for three song neighborhoods. $F^{*} \mathrm{ST}$ is a mean likelihood estimate of Wright's $F_{\text {ST; }}$ negative values are interpreted as equal to zero (Long, 1986). Different summary statistics are calculated for loci with two and three alleles. None of the $z$ values or $F$ ratios was significant $(P>0.05)$.

\begin{tabular}{|c|c|c|c|c|c|c|}
\hline Locus & $\begin{array}{c}\text { Number of } \\
\text { alleles }\end{array}$ & $F^{*} \mathrm{ST}$ & $\lambda$ & $x^{2}$ & $d f$. & $z$ \\
\hline $6 P g d$ & 3 & -0.0044 & 0.9442 & 3.2 & 4 & 0.049 \\
\hline Got & 3 & 0.0250 & 0.8759 & 7.1 & 4 & 1.127 \\
\hline$M p i$ & 3 & 0.0006 & 0.9117 & 3.8 & 4 & 0.177 \\
\hline Pept $B$ & 3 & -0.0002 & 0.9412 & 3.5 & 4 & 0.044 \\
\hline Locus & $\begin{array}{l}\text { Number of } \\
\text { alleles }\end{array}$ & $F^{*} \mathrm{ST}$ & $\lambda$ & $d f_{1}$ & $d . f_{2}$ & $F$ ratio \\
\hline$\alpha G p d$ & 2 & -0.0161 & 0.9881 & 2 & 59 & 0.356 \\
\hline$P g m$ & 2 & -0.0079 & 0.9773 & 2 & 59 & 0.685 \\
\hline$P g i$ & 2 & -0.0241 & 0.9984 & 2 & 58 & 0.046 \\
\hline$I d h$ & 2 & -0.0027 & 0.9665 & 2 & 52 & 0.902 \\
\hline Pept C & 2 & -0.0242 & 0.9959 & 2 & 55 & 0.112 \\
\hline
\end{tabular}


TABLE 5. Analysis of variance of measurements of indigo buntings in different song neighborhoods (groups), within the two study areas.

\begin{tabular}{lllcccccc}
\hline \hline \multirow{2}{*}{ Area } & Sex & Measurement & $\begin{array}{c}\text { Number of } \\
\text { birds }\end{array}$ & $\begin{array}{c}\text { Number of } \\
\text { groups }\end{array}$ & Mean (mm) & SD & $F_{\text {means }}$ & $F_{\text {var }}$ \\
\hline Niles & male & wing & 227 & 11 & 69.21 & 1.51 & 1.11 & 1.82 \\
& & bill & 227 & 11 & 10.60 & 0.43 & 0.74 & 0.62 \\
& & tarsus & 226 & 11 & 17.17 & 0.52 & 1.14 & 1.60 \\
& \multirow{4}{*}{ female } & wing & 157 & 9 & 64.38 & 1.57 & $2.66^{*}$ & 1.07 \\
& & bill & 158 & 9 & 10.66 & 0.39 & 0.73 & 0.41 \\
Reserve & male & tarsus & 157 & 9 & 16.85 & 0.53 & 1.29 & 0.37 \\
& & wing & 267 & 17 & 69.14 & 1.40 & 0.85 & 1.06 \\
& & bill & 269 & 17 & 10.54 & 0.44 & 0.81 & 0.39 \\
& & tarsus & 271 & 17 & 17.12 & 0.66 & 1.04 & $2.59 *$ \\
& female & wing & 81 & 5 & 64.39 & 1.39 & 1.09 & 1.55 \\
& & bill & 81 & 5 & 10.56 & 0.43 & 0.31 & 1.73 \\
& & tarsus & 81 & 5 & 16.72 & 0.62 & 0.72 & 1.94 \\
\hline
\end{tabular}

$* P<0.05$

pairs, however, was not associated with their morphometric similarity, nor was this explained by their genetic similarity (Table 2). Finally, morphometric traits of a male might indicate his genetic quality relative to other males in the population. If these were important, we would expect a trend in the size of the male relative to other males and in his breeding success. We compared the deviation of the male's measurement from the mean of all males $\left(\bar{x}-x_{i}\right)$ with the success of the pair (Table 2) and found no relationship between male size deviation and breeding success. In the 48 successful pairs that fledged at least one young, breeding success was independent of these measures of similarity as well. The results indicate no advantage to a female in choosing a male with a similar or complementary genotype, or a male with a particular body size.

Song, Breeding Success Compared among Dialects, and Mate Choice. - The hypothesis that females choose among males on the basis of which song they sing leads to the following predictions: 1) If song types indicate male fitness, then males with different song types (that is, males in different song neighborhoods) should have different success in attracting mates and in leaving offspring, particularly when the number of fledglings is compared across their lifetimes. 2) If females choose a mate by his song, then extrapair matings (female fertilized by an intruding male) should involve males with the same songs.

If males with certain songs tend to be more successful in their breeding and survival, then we might expect females to choose males with certain songs because these might indicate to her the quality of the male as a genetic parent to her offspring. The mating success of males with different song types gives one test of whether females are equally attracted to the various songs. Number of mates varies among males, but $85 \%$ of the mated male buntings have only one mate in a season, and the statistical differentiation of mating success is confounded by this lack of variation; none is obvious (Payne, 1982; Payne et al., 1988).

The lifetime breeding success of all males captured as yearlings in 1979 through 1984 was determined by summing the number of offspring that survived to fledge from all nests in their territories over all years through 1987. Song neighborhoods were compared where lifetime breeding success was determined for at least 10 males. Of the 94 males that were known to be resident for at least 28 days (time to mate, nest, and fledge a brood) in their first year, and for which we knew the number of young fledged in all years, seven were still alive through 1987 and their lifetime success is a minimal value. Mean lifetime breeding success did not differ significantly among neighborhoods at Niles or the Reserve (Table 6). The results indicate no significant difference in biological quality of males among song neighborhoods.

Male buntings sang most persistently before mating and less when they were mated 
TABLE 6. Analysis of variance of lifetime breeding success of male indigo buntings in different song neighborhoods (groups). None of the $F$ values was significant $(P>0.05)$.

\begin{tabular}{|c|c|c|c|c|c|c|}
\hline \multirow[b]{2}{*}{ Area } & \multirow{2}{*}{$\begin{array}{l}\text { Num- } \\
\text { ber of } \\
\text { birds }\end{array}$} & \multirow{2}{*}{$\begin{array}{l}\text { Num- } \\
\text { ber of } \\
\text { groups }\end{array}$} & \multicolumn{2}{|c|}{$\begin{array}{c}\text { Number of } \\
\text { offspring }\end{array}$} & \multirow[b]{2}{*}{$F_{\text {means }}$} & \multirow[b]{2}{*}{$F_{\text {var }}$} \\
\hline & & & Mean & SD & & \\
\hline Niles & 49 & 4 & 4.80 & 3.54 & 0.39 & 0.27 \\
\hline Reserve & 45 & 3 & 2.47 & 3.25 & 0.03 & 0.69 \\
\hline
\end{tabular}

(Thompson, 1972). During a female's copulation days, from zero to eight days before laying, the resident male on a territory was usually quiet and did not sing near the female. Perhaps because she had already formed a pair bond with him, the male avoided advertising her presence to neighboring males, and was perhaps actively guarding his mate. In comparing the genotypes of nestling broods and the adults resident near the nest and on the territory, in all but one brood all of the nestlings were consistent with the female but in $25 \%$ of the broods (36 of 145) sampled, at least one nestling was not consistent with the male (Westneat, 1986, 1987b). In no extrapair copulation attempt that we saw did the male sing, though intruding males often gave flight songs when chased by the resident.

Extrapair copulations were indicated by observations of an intruding male near the resident male's female and sometimes in cloacal contact with her, as well as from observed genotypes of her nestlings that were incompatible with her mate's. Most cuckolding males spent most of their time and sang on territories within $200 \mathrm{~m}$ of the male whose female they mated with (Westneat, $1987 a, 1987 b$ ). We compared the song of the male involved in extrapair mating attempts with the song of the resident male. We included only cases where the intruding male was banded and identified during our focal-animal observation periods, and where he made cloacal contact with her; males that attempted more than one mating during a single nesting cycle were counted only once. The intruder had the same song type as the resident in three instances and a different song type in four instances. In the two instances when we saw prolonged cloacal contact, the cuckolder had the same song type in one and a different song in the other.
More extrapair copulations were indicated by genotype incompatibilities than by behavior observations: 36 broods involving 34 bunting pairs had genotypes where a nestling did not match the resident male. In 22 of these, at least one neighboring male within $200 \mathrm{~m}$ had a genotype consistent with the genotypes of the excluded nestlings. In four of these the male had the same song type as the resident male, in 14 he had a different song type, and in four the resident male had more than one neighbor with the same genotypes as the nestling, one with his song type and one or more with a different song. Several song types were involved both for cuckolded males and for the successfully mating intruders. The number of males in a song neighborhood averaged $4.33 \pm 3.32$ $\mathrm{SD}$ ( $N$ neighborhood-years $=186$ at Niles), and in all but two of the 34 cases the cuckolded male had at least one neighbor with a matching song, so there was no trend for extrapair fertilizations to occur with a male that sang like the female's mate.

\section{Discussion}

Mate Choice for Genes?-The mating behavior of female indigo buntings may involve appraising and comparing different males, but we found no evidence of female choice of males either for traits that are obviously associated with genetic differences or for cryptic genetic differences. Mating appeared random for genes expressed in the electromorphs that we examined. Only a minute proportion of the genotype was sampled and is available through the standard techniques of protein electrophoresis. Other techniques might reveal additional variation within the loci sampled, but comparative evaluations of electrophoretic conditions have revealed little additional cryptic allelic variation in birds (Aquadro and Avise, 1982). We reason that the sampled loci are likely to be representative of polymorphic loci in general (Lewontin and Hubby, 1966), and that the differences are representative of the genetic differences among mates. However not all loci are equally likely in theory or practice to show heterosis or selective differences (Lewontin, 1974; Koehn et al., 1983; Slatkin, 1985; Endler, 1986), and other loci may be involved in mate choice. Because the traits were met- 
abolic enzymes, it is not obvious how their variation might be expressed in alternative behaviors or morphology available to female buntings as they assess potential mates. The lack of association in size between members of a pair further suggests that a female does not choose a mate by comparing his size to a common standard, or by comparing his size to her own, as may occur in assessment of genetic kin. Female Darwin's finches (Geospiza spp.) selectively mate with larger males, and body size is heritable (Boag, 1983; Price, 1984), so females might be able to assess male genetic quality through size in some songbirds.

Breeding success in the buntings was not related to genetic or size similarity among mates or to size of the mate, though any of these might indicate genetic quality. Mate choice for males with complementary genes might increase the proportion of heterozygous young, and heterozygotes in some species have an advantage in growth and reproduction (Koehn et al., 1983; Turelli and Ginzburg, 1983; Mitton and Grant, 1984). In buntings each locus sampled was homozygous in most individuals, and the proportion of heterozygotes observed was that expected from a binomial distribution in nearly all cases (Westneat, 1987b). Predators were the main cause of loss of eggs and nestlings and it is unlikely that the metabolic enzymes assayed were related to this source of nest failure. They could be related to growth and time of fledging, but they are unlikely to be the specific ones which affect differences in growth, development, and survival in buntings. The development of nestlings was not closely monitored, but no birth defects or unusually slow growth were observed. Size is heritable in buntings, but neither relative nor absolute male size predicts the fitness quality of the male to a female when she is choosing a mate.

Insofar as females are free to choose mates from different song neighborhoods, they might choose among males by their song. Song quality is very similar as far as we can detect from the audiospectrograms of individuals within a neighborhood. Song differences define the song neighborhoods, but mean lifetime breeding success of males does not differ among neighborhoods, and the song neighborhoods generally do not cor- respond to different habitats as they might if the songs covaried with local adaptations of populations (Payne, 1982). Our electrophoretic comparisons and dispersal data indicate no significant genetic differences among the song neighborhoods, so it seems unlikely that the observed similarity in lifetime male breeding success among neighborhoods is explained by equivalent but distinct differentiated adaptations among the neighborhoods.

Biological Differentiation of Song Neighborhoods?-The results of the genetic and morphometric comparisons of song neighborhoods in indigo buntings are consistent with the results of the observations of marked individuals. The neighborhoods characterized by songs are not genetically differentiated, the same alleles predominate in adjacent neighborhoods, and body size does not differ significantly among neighborhoods. Our direct observations of movements between natal and breeding neighborhoods show that the song neighborhoods are not isolated demes. Adult females sometimes switch mates and when they do they often switch song neighborhoods (Payne, $1983 b$ ). Buntings that were marked as nestlings and that return and breed in a later year in their natal population usually do not settle in their natal song neighborhood. Males usually sing the song of another neighborhood and not their father's song, and females usually do not mate within their natal neighborhood (Payne et al., 1987). Because the electrophoretic data alone provide such an incomplete index of the genetic differences among individuals and do not necessarily reflect the variability of the complete genome (Lewontin, 1974; Chakraborty, 1981), the dispersal data are critical in demonstrating a lack of population structuring at the level of the song neighborhood. The song-sharing neighborhoods in buntings appear to result from individual social adaptations, without evolutionary significance in relation to the differentiation of populations.

A similar interpretation has been proposed in other species where young disperse from their natal neighborhood and adapt their song behavior to match their new neighborhood after dispersal (Kroodsma, 1974; Verner, 1976; Jenkins, 1978) as well 
as where adults disperse and change their song to match their new population (Payne $1985 a, 1985 b$ ). An alternative has been suggested for some populations of whitecrowned sparrows (Zonotrichia leucophrys nuttalli) (Marler and Tamura, 1962; Baker et al., 1982). Song differences might affect dispersal so that birds avoid leaving their familiar natal neighborhood, and if dispersal is limited, the local populations may become genetically differentiated. Birds disperse across song neighborhoods to a much lesser degree in this resident species than in the buntings, which have much smaller neighborhoods and are seasonally migratory. Nevertheless, juvenile sparrows dispersed at least a few kilometers, and 4\% moved from one neighborhood to another (Baker and Mewaldt, 1978; Payne, 1981a). The observed dispersal pattern matched also an expected random dispersal model (Hafner and Petersen, 1985), though the trapping program was nonuniform and the dispersal data are difficult to interpret (Baker et al., 1985). Electromorph estimates of genetic differentiation were also low $\left(F_{\mathrm{ST}}=\right.$ 0.042 ) in the neighboring dialect sparrow populations, however, no significance tests were reported (Baker et al., 1982). About half of the variation in $F_{\mathrm{ST}}$ estimates among sparrow song neighborhoods can be attributed to microgeographic variation within neighborhoods (Zink and Barrowclough, 1984). Dispersal within a generation may be sufficient to explain the variation among neighborhoods and to prevent genetic differentiation. It remains an open question whether these song dialects are causally associated with dispersal behavior and genetic differentiation (Zink and Barrowclough, 1984; Zink, 1985; Hafner and Petersen, 1985; Baker et al., 1985).

Another view of the evolutionary significance of song dialects was proposed for chaffinches (Fringilla coelebs) by Simkin (1982), who described different song types for Russian chaffinches in pine, spruce, birch, and garden habitats and suggested that each represented a distinct genotype. In his view, birds might mate assortatively even after they had dispersed from their natal sites by recognizing song differences where these covaried with habitat. Simkin gave no genetic or developmental tests of his hy- pothesis. In principle, alternative behaviors such as these song types might be determined by genetic differences even if each developed only in a certain environment and if some genetic differences were expressed together in habitat selection and predispositions to learn certain songs. However, chaffinches learn their songs by hearing other chaffinches, and there is no evidence that certain songs are learned only by certain chaffinches (Slater and Ince, 1982), nor do chaffinch songs in other areas covary with habitat (Jenkins and Baker, 1984; Lynch and Baker, 1986). The songs of indigo buntings do not covary with habitat either (Payne, 1982).

Mate Choice for Song? - Because males do not differ in lifetime breeding success among song dialects, the dialects are biologically equivalent in terms of the mean fitness of the singers. The individual values for lifetime reproductive success for males are somewhat uncertain because extrapair copulations have occasionally been observed (Payne, 1983a; Westneat, 1987a) and not all young have genotypes consistent with the male on the territory where they were reared (Westneat, 1987b). We found no evidence that cuckoldry varies significantly among song dialects, and our behavior observations and genotypic evidence showed that some males were both cuckolded and also won extrapair fertilizations themselves.

Mate choice for song was also tested by comparing the song type of a female's father with the song of her first mate in those cases where a bird banded as a nestling returned and bred in the study area in a later year (Payne et al., 1987). A female that bred in her natal area usually mated with a male with a song different from her father's song, but a few females mated with a male with father's song, and two mated with the father himself. The fledging success of incestuous pairs was similar to the mean success of all pairs in the population, and the one offspring of an incestuous mating that returned bred successfully. Male buntings that return to their natal area usually have a song different from their father's, but a few have their father's song type. The proportion with a song like their father's is about that expected by chance, if first-year males copy songs in proportion to the number of birds 
that sing them locally in their first breeding season (Payne et al., 1987). Buntings reared in captivity do not sing their father's song when they are grown, but either have an abnormal isolate song or copy the song of another male bunting they hear in their first year of life, depending on their social experience (Payne, 1981b). Bunting songs carry no information about kinship as songs are not transmitted either culturally or genetically from father to son, so songs provide no cues to a female about this aspect of genetic quality of potential mates.

Because songbirds learn their songs, alternative song traits such as the song types of indigo buntings may be among the least likely of traits to be associated with mate choice for genes. Unless mate choice is shown to be associated with genetic differences among males and differential breeding success, a null or neutral model of no mate choice for genes is an appropriate interpretation of observed association of song traits and mating success.

\section{ACKNOWLEDGMENTS}

We thank S. M. Doehlert, L. L. Payne, and our research assistants for help in the field. Banding and biopsies were carried out under U.S. Fish and Wildlife Service Banding Permit 20080. For permits to work at Niles we thank Amtrak. The University of Michigan Museum of Zoology made available the lands and facilities of the E. S. George Reserve. J. C. Long and P. E. Smouse provided a program (F-STAT) for estimation and evaluation of $F$ statistics. J. B. Falls provided a translation of Simkin. L. F. Baptista, B. Crespi, R. L. Curry, F. S. Dobson, H. L. Gibbs, G. E. Hill, P. Myers, L. L. Payne, and J. M. Trainer offered comments on the manuscript. The research was supported by a University of Michigan Faculty Research Grant and NSF grants (BNS7803178, BNS8102404, BSR8317810) to R.B.P. and by the Department of Biology, University of North Carolina, the Frank M. Chapman Memorial Fund of the American Museum of Natural History, Sigma Xi, and NSF grant BSR8501075 to D.F.W.

\section{Literature Cited}

Aquadro, C. F., AND J. C. Avise. 1982. Evolutionary genetics of birds. VI. A reexamination of protein divergence using varied electrophoretic conditions. Evolution 36:1003-1019.

Avise, J. C., J. C. Patton, and C. F. Aquadro. $1980 a$. Evolutionary genetics of birds. I. Relationships among North American thrushes and allies. Auk 97:135-147.

- 1980b. Evolutionary genetics of birds. Conservative protein evolution in North American sparrows and relatives. Syst. Zool. 29:323-334.

Baker, M. C., AND L. R. Mewaldr. 1978. Song dialects as barriers to dispersal in white-crowned sparrows, Zonotrichia leucophrys nuttalli. Evolution 32:712-722.

Baker, M. C., D. B. Thompson, G. L. Sherman, M. A. Cunningham, and D. F. TOMBaCK. 1982. Allozyme frequencies in a linear series of song dialect populations. Evolution 36:1020-1029.

BAKER, M. C., D. F. TOMBACK, D. B. Thompson, AND M. A. Cunningham. 1985. Reply to Hafner and Petersen. Evolution 39:1177-1179.

Barrowclough, G. F., and K. W. Corbin. 1978. Genetic differentiation in the parulidae. Auk 95: 691-702.

BAteson, P. 1983. Optimal outbreeding, pp. 257277. In P. Bateson (ed.), Mate Choice. Cambridge Univ. Press, Cambridge, U.K.

BOAG, P. T. 1983. The heritability of external morphology in Darwin's ground finches (Geospiza) on Isla Daphne Major, Galápagos. Evolution 37:877894.

BOAG, P. T., AND P. R. GRANT. 1981. Intense natural selection in a population of Darwin's finches (Geospizinae) in the Galápagos. Science 214:82-85.

Chakraborty, R. 1981. The distribution of the number of heterozygous loci in an individual in natural populations. Genetics $98: 461-466$.

ENDler, J. A. 1986. Natural Selection in the Wild. Princeton Univ. Press, Princeton, NJ.

Fleischer, R. C., R. F. Johnston, AND W. J. KLITZ. 1983. Allozymic heterozygosity and morphological variation in house sparrows. Nature 304:628630.

Hafner, D. J., and K. E. Petersen. 1985. Song dialects and gene flow in the white-crowned sparrow, Zonotrichia leucophrys nuttalli. Evolution 39:687694.

HarRis, H., AND D. A. Hopkinson. 1976. Handbook of Enzyme Electrophoresis in Human Genetics. North-Holland, Amsterdam, Neth.

HARTL, D. L. 1980 . Principles of Population Genetics. Sinauer, Sunderland, MA.

Jenkins, P. F. 1978. Cultural transmission of song patterns and dialect development in a free-living bird population. Anim. Behav. 26:50-78.

Jenkins, P. F., AND A. J. BAKER. 1984. Mechanisms of song differentiation in introduced populations of chaffinches Fringilla coelebs in New Zealand. Ibis 126:510-524.

Koehn, R. K., A. J. Zera, and J. G. Hall. 1983. Enzyme polymorphism and natural selection, pp. 115-136. In M. Nei and R. K. Koehn (eds.), Evolution of Genes and Proteins. Sinauer, Sunderland, MA.

KroOdSMA, D. E. 1974. Song learning, dialects, and dispersal in the Bewick's wren. Z. Tierpsychol. 35: 352-380. 
Lewontin, R. C. 1974. The Genetic Basis of Evolutionary Change. Columbia Univ. Press, N.Y.

Lewontin, R. C., AND J. L. Hubby. 1966. A molecular approach to the study of genic heterozygosity in natural populations, II. Amount of variation and degree of heterozygosity in natural populations of Drosophila pseudoobscura. Genetics 54:595-609.

LONG, J. C. 1986. The allelic correlation structure of Gainj- and Kalim-speaking people. I. The estimation and interpretation of Wright's $F$-statistics. Genetics 112:629-647.

LYNCH, A., AND A. J. BAKER. 1986. Congruence of morphometric and cultural evolution in Atlantic island chaffinch populations. Can. J. Zool. 64:15761580.

Marler, P., AND M. Tamura. 1962. Song "dialects" in three populations of white-crowned sparrows. Condor 64:368-377.

MCGregor, P. K., AND J. R. Krebs. 1982a. Mating and song types in the great tit. Nature 297:60-61.

$1982 b$. Song types in a population of great tits (Parus major): Their distribution, abundance and acquisition by individuals. Behaviour 72:126152.

Mitton, J. B., AND M. C. Grant. 1984. Associations among protein heterozygosity, growth rate, and developmental homeostasis. Ann. Rev. Ecol. Syst. 15: 479-499.

Parker, G. A. 1983. Mate quality and mating decisions, pp. 141-164. In P. Bateson (ed.), Mate Choice. Cambridge Univ. Press, Cambridge, U.K.

PAYNe, R. B. 1981a. Population structure and social behavior: Models for testing the ecological significance of song dialects in birds, pp. 108-120. In R. D. Alexander and D. W. Tinkle (eds.), Natural Selection and Social Behavior. Chiron, N.Y.

- $1981 b$. Song learning and social interaction in indigo buntings. Anim. Behav. 29:688-697.

- 1982. Ecological consequences of song matching: Breeding success and intraspecific song mimicry in indigo buntings. Ecology 63:401-411.

- $1983 a$. Bird songs, sexual selection, and female mating strategies, pp. 55-90. In S. K. Wasser (ed.), Social Behavior of Female Vertebrates. Academic Press, N.Y.

- $1983 b$. The social context of song mimicry: Song-matching dialects in indigo buntings (Passerina cyanea). Anim. Behav. 31:788-805.

- 1985a. Behavioral continuity and change in local song populations of village indigobirds Vidua chalybeata. Z. Tierpsychol. 70:1-44.

- $1985 b$. Song populations and dispersal in steelblue and purple widowfinches. Ostrich 56:135146.

Payne, R. B., L. L. Payne, and S. M. Doehlert. 1987. Song, mate choice and the question of kin recognition in a migratory songbird. Anim. Behav. 35: $35-47$.

-1988. Biological and cultural success of song memes in indigo buntings. Ecology 69:104-117.

Payne, R. B., W. L. Thompson, K. L. Fiala, and L. L. SWEANY. 1981. Local song traditions in indigo buntings: Cultural transmission of behavior patterns across generations. Behaviour 77:199-221.

Price, T. D. 1984. Sexual selection on body size, territory and plumage variables in a population of Darwin's finches. Evolution 38:327-341.

SearCy, W. A., and M. Andersson. 1986. Sexual selection and the evolution of song. Ann. Rev. Ecol. Syst. 17:507-533.

Selander, R. K., M. H. Smith, S. Y. Yang, W. E. Johnson, AND D. E. GenTRY. 1971. Biochemical polymorphism and systematics in the genus Peromyscus. I. Variation in the old field mouse (Peromyscus polionotus). Univ. Texas Publ. Stud. Genet. $7103: 49-90$.

Shaw, C. R., and R. Prasad. 1970. Starch gel electrophoresis of enzymes-a compilation of recipes. Biochem. Genet. 4:297-320.

Sherman, P. W. 1981. Kinship, demography, and Belding's ground squirrel nepotism. Behav. Ecol. Sociobiol. 8:251-259.

Sherman, P. W., and W. G. Holmes. 1985. Kin recognition: Issues and evidence, pp. 432-460. In B. Hölldobler and M. Lindauer (eds.), Experimental Behavioral Ecology and Sociobiology. Sinauer, Sunderland, MA.

SHIELDS, W. M. 1982. Philopatry, Inbreeding, and the Evolution of Sex. State Univ. Press, Albany, N.Y.

SIMKIN, G. N. 1982. Modern problems in the study of vocal communication in birds. Ornitologiya 17: 36-53. (In Russian, translated by Multilingual Services, Secretary of State, Canada.)

Slater, P. J. B., AND S. A. InCE. 1982. Song development in chaffinches: What is learnt and when? Ibis 124:21-26.

SlatKIN, M. 1985. Gene flow in natural populations. Ann. Rev. Ecol. Syst. 16:393-430.

SMOUSE, P. E., AND J. C. LoNG. 1988. A comparative $F$-statistics analysis of human populations from lowland South America and highland New Guinea, pp. 32-46. In B. S. Weir, G. Eisen, M. M. Goodman, and G. Namkoong (eds.), Proceedings of the II International Conference of Quantitative Genetics. Sinauer, Sunderland, MA.

Tномpson, W. L. 1970. Song variation in a population of indigo buntings. Auk 87:58-71.

- 1972 . Singing behavior of the indigo bunting. Z. Tierpsychol. 31:39-59.

Turelli, M., AND L. R. Ginzburg. 1983. Should individual fitness increase with heterozygosity? Genetics 104:191-209.

VERNER, J. 1976. Complex song repertoire of male long-billed marsh wrens in eastern Washington. Living Bird 14:263-300.

Westneat, D. F. 1986. Parental care and alternative mating tactics in the indigo bunting. Ph.D. Diss. Univ. North Carolina, Chapel Hill.

- 1987a. Extra-pair copulations in a predominantly monogamous bird: Observations of behaviour. Anim. Behav. 35:865-876.

- $1987 \mathrm{~b}$. Extra-pair fertilizations in a predominantly monogamous bird: Genetic evidence. Anim. Behav. 35:877-886.

Westneat, D. F., R. B. Payne, and S. M. Doehlert. 1986. Effects of muscle biopsy on survival and breeding success in indigo buntings. Condor 88 : 220-227.

WrIGHT, S. 1978. Evolution and the Genetics of Pop- 
ulations, Vol. 4. Variability Within and Among Natural Populations. Univ. Chicago Press, Chicago, IL.

ZINK, R. M. 1982. Patterns of genic and morphologic variation among sparrows in the genera Zonotrichia, Melospiza, Junco, and Passerella. Auk 99:632638.
1985. Genetical population structure and song dialects in birds. Behav. Brain Sci. 8:118-119.

Zink, R. M., AND G. F. BARrowClough. 1984. Allozymes and song dialects: A reassessment. Evolution 38:444-448.

Corresponding Editor: C. F. Aquadro 